\title{
Innovation and expansion: Product innovation and expansion in insurance in South Africa. \\ The case of Sanlam, 1920-1998
}

\section{Grietjie Verhoef}

\begin{abstract}
The insurance industry is generally perceived to be a conservative, risk averse enterprise following market developments rather than leading them. This article explores the development of innovation in the South African long-term insurance market in the context of the development of the South African economy after the formation of the Union of South Africa. A leading role player in this market is Sanlam, a company leading the South African long-term insurance industry in product innovation. This article investigates the strategy used by Sanlam to establish itself in a market dominated by British insurance companies. It then explores the use of product innovation by Sanlam since the early 1920s to expand its market share. The competitive advantage acquired by Sanlam in the insurance industry by the end of the twentieth century paved the way for subsequent expansion and diversification.
\end{abstract}

Key words: Product development; longevity; long term insurance; disability; premiums; investments.

\section{Opsomming}

'n Algemene aanname oor die versekeringsbedryf is dat dit 'n konserwatiewe, risikovermydende sektor is wat eerder markneigings navolg as om dit te inisieer. Hierdie artikel ondersoek die ontwikkeling van innovering in die Suid-Afrikaanse langtermynversekeringsmark teen die agtergrond van die ontwikkeling van die ekonomie na die totstandkoming van die Unie van Suid-Afrika. 'n Onderneming wat 'n leidende rol in hierdie mark in Suid-Afrika gespeel het, is Sanlam wat in die langtermynversekeringsmark op die voorpunt van produkontwikkeling is. Verder word ondersoek ingestel na die strategieë wat deur Sanlam gevolg is om die maatskappy te vestig in hierdie mark wat aanvanklik deur Britse maatskappye oorheers is. Die artikel ondersoek Sanlam se gebruik van produk-innovasie sedert die vroeë 1920's om hul markaandeel te vergroot. Die mededingende voordeel wat

* Grietjie Verhoef is professor in Economic and Accounting History in the Department of Accountancy at the University of Johannesburg, South Africa. She can be contacted at gverhoef@uj.ac.za

\section{How to cite this article:}

G. Verhoef, "Innovation and expansion: Product innovation and expansion in insurance in South Africa. The case of Sanlam, 1920-1998", Historia 61, 1, May/Mei 2016, pp 66-91. http://dx.doi.org/10.17159/2309-8392/2016/v61n1a7

Copyright: (CThe Author(s). Published under a Creative Commons Attribution Licence. 
Sanlam teen die einde van die twintigste eeu verwerf het, het die grondslag gelê vir daaropvolgende uitbreiding en diversifikasie.

Sleutelwoorde: Produkontwikkeling; langlewendheid; langtermynversekering; ongeskiktheid; premies; beleggings.

\section{Introduction}

The South African insurance market was well developed by the beginning of the twentieth century. By 1910, 23 insurance companies were active in the Union, of which only nine were locally incorporated companies, the insurance industry being dominated by British insurers at the time. ${ }^{1}$ This highlighted the success of the South African National Life Assurance Company (Sanlam) as a latecomer. In a competitive market it outperformed the established companies which called for innovative product offering and marketing. Established in 1918, Sanlam entered an insurance environment where innovative strategies held the key to survival. ${ }^{2}$

The simple research question is: How did Sanlam establish itself in the competitive South African insurance market among established, trusted life offices? In this paper the use of innovation, diversification, competitiveness and corporate citizenship in Sanlam is illustrated as functional to the growth of the company. From a ranking of 24th among life offices in 1918, it became the second largest long-term insurance company in South Africa by the end of the century. A convergence or triangulation of innovation, competitiveness and corporate citizenship over a period of about eighty years, supplemented by leading-edge marketing, afforded this latecomer the ability to compete effectively and capture a significant market share.

The paper first explains the nature of long term insurance as an industry and then addresses Sanlam's growth strategies against the historical context of the South African economy. First, the period 1918 to 1950 is discussed, with the emphasis on strategies to grow its market in a time of wars and depression. The second period is 1950 to 1990, with an analysis of the market penetration strategies and the relative performance of Sanlam in the industry. The article concludes by explaining Sanlam's response to the contextual changes and competitive pressures in both the domestic and global markets, leading to strategic changes in 1998.

1. Official Year Book of the Union of South Africa, 1910-1917, p 724; G. Verhoef, "South Africa: Leading African Insurance", in P. Borscheid and N.V. Haueter (eds), World Insurance: The Evolution of a Global Risk Network (OUP, Oxford, 2012), pp 325-348.

2. R. Pearson, "Introduction: Towards an International History of Insurance", in R. Pearson (ed.), The Development of International Insurance (Pickering \& Chatto, London, 2010), pp 1-24; J. Darroch and M. Kipping, “Canada: Taking Life Insurance Abroad", in Borscheid and Haueter (eds), World Insurance, pp 252-273; G. Blainey, A History of the AMP, 1848-1998 (Allen \& Unwin, St Leonards, 1998). 


\section{The world of insurance in South Africa: innovation and stability}

The historiography on South African insurance business, especially the insurance industry, is scant. A few coffee table marketing exercises were published ${ }^{3}$ and Vivian published brief histories of insurance enterprises before market concentration in the 1990s. ${ }^{4}$ Few historians have engaged themselves with South African Business History. However, the history of the economic development of South Africa has been expertly documented by Arndt, De Kock, Schumann, Houghton, Nattrass, Jones and Müller and recently, more sweepingly, by Feinstein. These studies are informed by a sound understanding of economic theory and macro-economic cycles of the international economy, which constituted the context of the development of the open domestic economy.

Sanlam was established in 1918, at a time when South Africa's post-war economy prospered, but where white Afrikaner poverty remained rife. ${ }^{5}$ Sanlam was established to expand Afrikaner interests in the financial services industry, and at the same time, as a strategy to address white poverty by encouraging people to take financial responsibility by saving though life assurance products for their future and that of their children. ${ }^{6}$ Sanlam made steady, but slow progress as the South African

3. See for example, O. Knaggs, Norwich Life, 1706-1990 (Oliver Knaggs \& Associates, Cape Town, 1990); R. van Selm, The History of the South African Mutual Life Assurance Society, 1845-1945 (SA Mutual, Cape Town, 1945); and P.B. Simons, Old Mutual, 18451995 (Human \& Rousseau, Cape Town, 1995).

4. R.W. Vivian, "A History of the South African Fire and Life Assurance Company", South African Journal of Economic History, 11 (1996); R.W. Vivian, "A History of the London and Lancashire Fire Insurance Company in South Africa", South African Journal of Economic History, 17 (2002); R. Vivian, The Story of Mutual and Federal, 1831-1995 (Mutual and Federal Insurance Company, Johannesburg, 1995).

5. The extent of this poverty was described by De Kiewiet as "At the base of white society had gathered, like a sediment, a race of men so abject in their poverty..." See C.W. de Kiewiet, A History of South Africa: Social and Economic (Clarendon Press, Oxford, 1942), pp 162-169, 181-182; M.H. de Kock, Selected Subjects in the Economic History of South Africa (Juta, Cape Town, 1924), pp. 455-456; C. Feinstein, An Economic History of South Africa (Cambridge, CUP, 2005), pp 82-85.

6. This paper does not aim to repeat the extensive literature on the establishment of Sanlam, or the why and how of its establishment and its growth. On this see G. Verhoef, "Nationalism, Social Capital and Economic Empowerment: Sanlam and the Economic Upliftment of the Afrikaner People, 1918-1960", Business History, Special Issue: Putting Social Capital to Work, 50, 6(2008), pp 694-713; and G. Verhoef, "Savings for Life to Build the Economy for the People: The Emergence of Afrikaner Corporate Conglomerates in South Africa, 1918-2000", The South African Journal of Economic History, 24,1(2009), pp 118-163. See also D. Welsh, "The Political Economy of Afrikaner Nationalism", in A. Leftwich (ed.) South Africa: Economic Growth and Political Change (Allison \& Bushby, London, 1974), pp 249-285; H. Giliomee, The Afrikaners. Biography of a People (Tafelberg, Cape Town, 2003), p 388; W.P.G. Koen, "Sanlam tussen die Twee Wêreldoorloë: Systigting, Groei en Stryd om 'n Ekonomiese Staanplekvir die Afrikaner, 1918-1939”, MA dissertation, UNISA, 1986; J.P Scannell, Uit die Volk Gebore: Sanlam se Eerste Vyftigjaar (Nasionale Boekhandel, Kaapstad, 
economy struggled through the devastatingly adverse effects of the 1929 depression exacerbated by the drought of 1932-33. ${ }^{7}$

Although insurance products were available irrespective of ethnicity, race, or creed, the distinguishing factor was the ability to pay for insurance. The growth of financial services, including insurance, was therefore primarily, but never exclusively, aimed at the European population, or persons with stable incomes. This portion of society increased with industrialisation and urbanisation, which in South Africa occurred from the late 1920s and early 1930s. ${ }^{8}$ South Africa followed the trend found in industrial centres of the USA where the urbanised populations developed the need for insurance to secure life and social status. ${ }^{9}$

Sanlam leveraged the unstable financial position of Afrikaners, the nationalism and solidarity displayed during the 1914 Rebellion and the success achieved with the establishment of De Burger in 1915, to grow a new business, that of insurance. Afrikaner nationalism was further mobilised through the Eerste Ekonomiese Volkskongres (first economic congress of the people) of 1939 to speed up Afrikaner participation in the mainstream South African economy. ${ }^{10}$ In the period up to the 1950s Sanlam used the cyclical growth of the South African economy, the plight of poor whites and Afrikaner nationalism to stimulate demand for its insurance products.

The literature on innovation in the insurance industry is limited. ${ }^{11}$ Pearson suggested that cycles of process and product innovation in insurance displayed a weak and lagged inverse relationship between insurance innovation and innovation in industrial production. When industrial expansion slows down, there is a tendency in the insurance industry to take on new risks and develop new products. This is the case because liquidity pressures slow down as interest rate increases contributes to a slowdown in industrial growth. ${ }^{12}$ Silber also ascribed to the idea that high and volatile interest rates were aligned to liquidity constraints, which then induces innovation. ${ }^{13}$

1968); "Sanlam: A Profile of Progress", Supplement in The Manufacturer, July 1961; "The Sanlam Story", Financial Mail, March 1962.

7. De Kock, Selected Subjects in Economic History, pp 130-132; De Kiewiet, A History of South Africa, p 222.

8. De Kiewiet, $A$ History of South Africa, pp 222-223, 264-265; De Kock, Selected Subjects in Economic History, pp 456-457.

9. See S.A. Murphy, Investing in Life Insurance in Antebellum America (Johns Hopkins University, Baltimore, 2010).

10. See H. Giliomee, "The Afrikaner Economic Advance", in H. Giliomee and H. Adam, Ethnic Power Mobilized. Can South Africans Change? (Yale University Press, New Haven and London, 1979), pp 149-169.

11. D. Jenkins and T. Yoneyama, History of Insurance, Volumes 1-8 (Pickering \& Chatto, London, 2000).

12. R. Pearson, "Towards a Historical Model of Services Innovation: The Case of the Insurance Industry, 1700-1914", Economic History Review, 50, 2(1997), pp 235-256.

13. W.L. Silber, "Recent Structural Change in the Capital Markets: The Process of Financial Innovation", The American Economic Review, 73 (May 1983), pp 89-95. 
The so-called "modern"14 insurance industry developed out of the burial clubs or friendly societies of the late eighteenth and early nineteenth century. ${ }^{15}$ Insurers were characterised by caution which hampered product innovation ${ }^{16}$ in both the shortterm and long-term insurance markets ${ }^{17}$ and the life assurance market was especially conservative since it adhered to the principle of prudence imperative. However, the inherent nature of insurance business changed during the twentieth century, when markets and classes of business were expanded. ${ }^{18}$ The most important innovation was that insurance companies increasingly became composite companies offering different classes of insurance, and these companies expanded operations over such vast geographical areas that branches became the logical way of organising the extensive operations. ${ }^{19}$ Life offices showed more innovation in their investment policies, ${ }^{20}$ modernising and creating investment products which transformed ordinary life insurance. ${ }^{21}$

South African insurance mirrored British developments. The fire insurance industry in South Africa was dominated by British companies. ${ }^{22}$ As life business revolves more around trust and confidence, the life business was dominated by South African companies. The number of foreign companies exceeded South African life

14. Not even the introduction of fire insurance in the eighteenth century is regarded as entirely "modern" since evidence is that the development of fire insurance was slow and cautious. See R. Pearson, Insuring the Industrial Revolution: Fire Insurance in Great Britain, 1700-1850 (Ashgate, Aldershot, 2004), p 4.

15. M. Keller, The Life Insurance Enterprise, 1885-1910: A Study on the Limits of Corporate Power (Harvard University Press, Harvard MA, 1963), pp 4-6; L. Dennett, A Sense of Security: 150 years of Prudential (Granta Publications, Cambridge, 1998), pp 4-6; T. Alborn and S. Murphy, Anglo-American Life Insurance, 1800-1914, 3 Volumes, (Pickering \& Chatto, London, 2013), Vol. 1, p xi.

16. Pearson, Insuring the Industrial Revolution, p 184.

17. Jenkins and Yoneyama, History of Insurance, pp 33-36.

18. C. Trebilcock, Phoenix Assurance and the Development of British Insurance, Volume 1, 1782-1870 (Cambridge University Press, Cambridge, 1985).

19. Jenkins and Yoneyama, History of Insurance, pp 33-36; Alborn and Murphy, AngloAmerican Life Insurance.

20. R.E. Wright and G.D. Smith, Mutually Beneficial. The Guardian and Life Insurance in America (New York University Press, New York, 2004), pp 351-355.

21. J.D. Cummins and B. Venard (eds), Handbook of International Insurance (Springer, New York, 2007).

22. H. Spyrou, "The Development of the Insurance Business in the Union of South Africa", in South African Journal of Economics, 4 (1955), pp 325-340; H.M. Hirsch, "Early Days of Insurance in South Africa, 1826-1860", in African Insurance Record, September 1962; R.J. Miller, Life Assurance in South Africa (Blue Crane Books, Johannesburg, 1968); B.C. Benfield, "South African life Insurance: Circumstances, Significance and Techniques", PhD thesis, University of the Witwatersrand, 1987; Vivian, "A History of the London and Lancashire Fire Insurance Company in South Africa", pp 138-161; G. Verhoef, Life Offices to the Rescue: A History of the Role of Life Insurance in the South African Economy during the Twentieth Century", in Pearson (ed.) The Development of International Insurance, pp 145-166; Verhoef, "Leading African Insurance”, pp 325348. 
companies, but the local companies dominated the number of policies and the volume of premium income. ${ }^{23}$ The role of cultural alignment in establishing and nurturing trust in the business of a life company was vividly illustrated in the development of the life assurance industry in South Africa. South African companies offered the basic range of life assurance policies, but sought to enhance market penetration through leadership and social connectivity and sought efficiency gains by adherence to cost and delivery requirements. ${ }^{24}$ As saving through insurance assists in creating net increments of trust and security, it raises confidence to invest, produce and consume. This paper explores Sanlam's ability to develop skills in the insurance industry, hitherto dominated by non-Afrikaans entrepreneurs in South Africa. It looks at Sanlam's development of innovative products that spoke directly to the needs of a specific niche of their market ${ }^{25}$ which in turn encouraged people who had a weak culture of financial provision for their future and their families, to mobilise their savings to that goal.

\section{Entry and growth: the crucial years, 1918-1950}

Sanlam commenced business in June 1918. South Africa was in the throes of the First World War, coping with social upheaval and growing white poverty. The establishment of the Suid-Afrikaanse Nasionale Trust en Assuransie Maatskappy (SANTAM) on 1 May 1918 was the beginning of a short-term and long-term insurance company, or in fire and accident insurance and life assurance. It was soon apparent that the life business should be conducted in a separate company. Santam's lawyer, one De Villiers, advised the founders that it would be very difficult to protect the life fund of a joint concern against claims of creditors of the short term side of the business. Therefore on 8 June 1918, the Suid-Afrikaanse Lewens Assuransie Maatskappy (SANLAM) was established as a subsidiary of Santam. ${ }^{26}$

When Sanlam entered the insurance market for life assurance, more than 30 other companies sold life cover. ${ }^{27}$ In order to penetrate the life market, the Sanlam leadership realised that the company had to target marginalised Afrikaners by offering products that would address the needs of relatively poor whites, especially

23. Verhoef, "Leading African Insurance”, pp 325-348.

24. Mokyr recently underlined the centrality of cultural explanations alongside those of institutional factors in explaining differences in economic performance. See J. Mokyr, "Cultural Entrepreneurs and the Origin of Modern Economic Growth", in Scandinavian Economic History Review, 61, 1 (2013), pp.1-33.

25. An honourable mention should include Sanlam's remarkable ability to link its clients' savings effort to the general strengthening of the South African economy This began shortly after Sanlam's inception and in the early years it fervently supported the ideal expressed by J.B.M. Hertzog of "South Africa first". See G. Verhoef, "Die Ontwikkeling in die Gemeenskap: Korporatiewe maatskaplike betrokkenheid deur Sanlam, 19181980", Tysdkrif vir Geesteswetenskappe, 54, 4 (2014), pp 736-738.

26. Verhoef, "Nationalism, Social Capital and Economic Empowerment", pp 694-713.

27. The most important competition for Sanlam was the South African Mutual Life Assurance Society (Old Mutual, as it was later known). This was a South African mutual life office, doing business since 1845 . 
Afrikaners, and conduct their enterprise on sound business principles. The Sanlam policies were always offered to the broad public, with all policies available in both Afrikaans and English, and even German, right from the start. ${ }^{28}$ The first policies Sanlam developed, were aiming at two market segments - the ordinary life market and the industrial policy market. Industrial policies were typically sold to weekly wage earners and premiums were collected weekly from the policy holders. ${ }^{29}$ The industrial section of Sanlam was soon transferred to African Homes Trust (AHT), a company specialising in industrial policies and acquired by Santam in August $1918 .^{30}$

Sanlam had another serious constraint upon commencing business: there were no qualified Afrikaans-speaking accountants, actuaries; nor was there a steady supply of trained insurance agents to tap into. Sanlam compensated with an eclectic workforce, appointing a number of non-Afrikaans people with experience in the insurance industry ${ }^{31}$ and attempted to draw Afrikaners employed by the British insurance companies. ${ }^{32}$ These men constituted a core of staff that performed their duties on two levels: they executed the tasks to which they were appointed, and they actively engaged in encouraging young people to take up a career in insurance. ${ }^{33}$ This was a very slow, long process but was seen by the management team as part of the empowerment of Afrikaners.

The policies offered by Sanlam from the outset, were ordinary whole life policies for persons between 21 and 60 years of age, whole life policies with limited premiums, child inheritance policies, child inheritance policies without the termination of premiums after the death of the parent, and endowment policies. ${ }^{34}$ This was nothing new in the market, but what was unique was that policies were available in Afrikaans and were marketed by Afrikaans people to whom new entrants to the life market could relate. The only difference between Sanlam's reversionary

28. S. Halleen, "From Life Insurance to Financial Services: A Historical Analysis of Sanlam's Client Base, 1918-2004", PhD thesis, Stellenbosch, 2013, pp 87-93.

29. This form of insurance was introduced by the Prudential Insurance Company in Britain. See Alborn and Murphy, Anglo-American Life Insurance, pp xxxi.

30. Sanlam Archives (hereafter SA), A, 5/2/1, Sanlam Annual Report, 1919.

31. Alfred Macdowall was appointed as general manager and secretary; J.H. Harris as agency manager; Reginald Scott-Hayward, an Irishman with experience in fire insurance, as manager of casualties; Simon J.P. West as fire manager; and George Patterson, the actuary of African Homes Trust, was appointed as Sanlam's actuary.

32. Examples were Jan Pieter Feenstra and Harry van Dam, who left his position at the London and Lancashire Insurance Company, to join Sanlam. Harris resigned his position only five days after the establishment of Sanlam on 8 June 1918 and was replaced by an attorney G.F.S. de Villiers. See Verhoef, "Nationalism, Social Capital and Economic Empowerment”; Scannell, Uit die Volk Gebore, pp 9-17; SA, 6/1/7, M.S. Louw Papers, Memoirs.

33. Sanlam offered in-house training and later also financial support for university studies towards the professional skills they needed, such as actuarial science, accounting, and management. See SA, 6/5/1, J.P. Feenstra Correspondence; and SA, Policy Records PR1, Policies 744 and 745.

34. SA, $1 / 2 / 1 / 3$, Rate Book, 1931-1936). 
bonuses (bonuses earned on the investment return on insurance policy premiums) and bonuses offered by other insurance companies, was that Sanlam's were calculated and paid on annual valuations since September 1919.35 The Stone \& Cox Life Assurance tables of 1920 noted that Sanlam was the only insurance company established in South Africa to conduct such annual valuations. ${ }^{36}$ Another cutting edge innovation of the Sanlam policies was the offering of lump sum disability cover on all its policies, that is the payment of the sum assured in a lump sum should a policy holder become "totally and permanently disabled" - the latter being interpreted "liberally", according to Stone \& Cox, as the loss of two limbs, blindness, etc. ${ }^{37}$ The Sanlam disability benefit was more risky than instalment payments, but it was argued that a disabled person needed immediate relief due to sudden unexpected expenses. The sound business aspect of this decision was that the company settled a liability, whereas instalment disability cover could continue for indefinite periods. Two coloured persons were also appointed as agents in 1918. ${ }^{38}$ The Dagelijks Bestuur (the body that handled day-to-day management) supervised the training of agents under the agency manager, Feenstra, by considering weekly reports on agency matters. ${ }^{39}$

These policies endorsed the vision of the general manager, W.A. Hofmeyr, ${ }^{40}$ that the company sought to assist policyholders in providing for their families in case of the breadwinner not being able to do so, for the education of their children and the broad development of the economy of the country. Hofmeyr emphasised the concept of "mutuality", "duty" and "pride" that would be engendered in policyholders as they contributed to the well-being and development of their families, their communities and the country at large. ${ }^{41}$

Sanlam was using the relative poverty and existential insecurity among many Afrikaners and a nationalistic appeal on South Africans to support South African businesses that invested in the future of the country, to take a stand in the market for life assurance. The public responded positively to these calls, since Sanlam issued a record number of policies in its first year, namely 3228 , to a total value of $£ 1138.42$ It was recognised that the post-war economic prosperity added to the favourable

35. Other competitors in the life insurance industry varied the terms of their calculations - the general term being 3 years.

36. SA, $1 / 2 / 1 / 1 / 2$, Stone \& Cox Life Insurance Tables, 1920, p xi.

37. SA, $1 / 2 / 1 / 1 / 2$, Stone \& Cox Life Insurance Tables, 1920, p xi.

38. SA, F22/11/85, Sanlammer, 61, 40 (5 March 1993).

39. This is reflected in each set of Minutes of the Sanlam Dagelihjks Bestuur. See SA, Minute Books, Weekly Minutes of Management.

40. William Angus (Willie) Hofmeyr was born in Montagu, the son of Servaas Hofmeyr, a "dominee" or minister in the Dutch Reformed Church (DRC). See H.R. Malan, William Angus Hofmeyr, South African Dictionary of Biography, Vol. 3 (HSRC, Pretoria, 1977), pp 416-418; N.J. le Roux, W.A. Hofmeyr: Sy Werk en Waarde (Nasionale Boekhandel, Cape Town, 1953), pp 108-110 and 163-164; Die Sanlam Fakkel, December 1947, p 2; Die Sanlam Fakkel, November 1953, pp 24-31.

41. SA, JV 5/2/1, Sanlam Annual Reports, 23 December 1919, p 2; 22 December 1920, p 3; and 21 December 1921, p 3.

42. SA, JV 5/2/1/, Sanlam Annual Report, 23 December 1919, p 1. 
conditions of launching the new life office, but the fortunes of the de-linking of the British currency from the USA dollar in March 1919, turned to inflationary pressures in the UK as well as in South Africa. ${ }^{43}$ This soon led to the typical post-war depression, which only eased by 1922. In 1921 new business at Sanlam dropped by £31 381 to $£ 1116589.44$ A new low of only $£ 702792$ in new policies was written in 1922, followed by a slow recovery. 45

Sanlam management included a very bright, ambitious and patriotic young man, Marthinus Smuts Louw. ${ }^{46}$ He was inspired by the potential of actuarial science and devoted his professional career to finding ways of enhancing life products as a means to deliver better service to policy holders. As a young actuary at Sanlam, and an inspired Afrikaner nationalist, he used every opportunity to serve the competitiveness of Sanlam; in 1922 Sanlam announced a first for the South African life assurance industry and Louw was the mastermind behind it. ${ }^{47}$

This new policy was called the Ideal Policy. It introduced the concept of income protection through insurance, a brand new concept M.S. Louw had been introduced to in Holland in 1920.48 The idea was that the death of a breadwinner would secure the family not only a lump sum benefit, but regular income, on a weekly or monthly basis. This type of policy, launched on 1 May 1922, provided endowment benefits as family income benefits, while ordinary endowment policies could also be issued to a family (the "gesin"). In the context of the destitution caused by the 1929 depression, Sanlam added more products to strengthen the safety net for families the security of a regular income. In 1929 and 1931, Sanlam added the whole life policy with family income benefits, income protection insurance, which was endowment insurance with family income benefits; and the family income protection insurance with limited instalments and family income benefits at death. ${ }^{49}$

In the time of utter despair following the 1929 depression, Sanlam introduced the first ever group pension scheme for institutions, such as municipalities, regional

43. E.H.D. Arndt, Banking and Currency Development, 1652-1927 (Juta, Cape Town, 1928), p 412; De Kock, Selected Subjects in Economic History, pp 131-132.

44. SA, Minutes, General Management, 12 December 1921.

45. SA, Minutes, General Management, 18 November 1922.

46. Marthinus Smuts Louw (Tienie) was born on 15 August 1888 and died on 1 March 1979 in Cape Town. See Dictionary of South African Biography, Volume 1, p 471.

47. SA, Minutes of Board of Directors, 21 December 1921.

48. Louw visited the Netherlands after completing his actuarial training in Scotland. The Sanlam management maintained close contact with the international insurance industry. References were made in the minutes of the Board of Directors to participation in congresses and other links with insurance companies overseas. See SA, 6/5/1, Minutes of Board Meetings, 29 April 1921 and 4 April 1922. Sanlam was also a member of LIAM (an international non-profit organisation of life assurers) and attended regular training and research meetings of LIAM (see SA, Die Sanlam Fakkel, December 1962, pp 8-9).

49. SA, 1/2/1/3, Rate Books of 1922 and 1929. 
councils or other organisations unable to set up their own pension schemes. The concept of group employee benefits or social security was not only unfamiliar in the local insurance industry but also unknown in the British Commonwealth countries. ${ }^{50}$ Group policies were less expensive and offered cover to groups based on the collective entity and the shared destiny of persons working together. Group policies paid smaller commission to agents, but Sanlam motivated the introduction of such products as a service to society in times of growing insecurity. ${ }^{51}$ In the absence of statutory provision for such schemes, the company used its acquaintance with the staff 52 to make submissions to decision-makers. Sanlam assisted the Cape Provincial Administration in preparing ordinances providing for municipalities and regional councils to contract with insurance companies to set up and administer group pension schemes on behalf of such authorities. The idea to embark on group employee benefits started with W.J. Bezuidenhoudt, the general manager of Sanlam's agents. He spotted the entrepreneurial opportunity in the market: group benefits delivered bulk new policy holders, offered the opportunity to market the company's expertise and service and thereby automatically afforded it competitive access to a new market. The actuarial department developed the products and this ensured that Sanlam once again took the lead in the life assurance industry.

The 1930s were difficult years for South Africans. Primary product prices slumped during the depression and mining was adversely affected for the same reasons. Furthermore, South Africa's determination to cling to the gold standard from 1930 to 1932 proved disastrous to the economy. Only after South Africa joined Britain in abandoning the gold standard in December 1932, did the value of the local currency recover and exports resume. Total premiums of life assurance rose by only 1.2 percent between 1929 and 193453 and Sanlam realised it needed to get momentum restored in its business. One way of doing this was to target a sympathetically cultural-aligned sector of society, the teaching community, as a potential market.

Once again Sanlam built on its initial marketing call to self-sufficiency and responsibility of the breadwinner for the future of his/her dependents. The

50. Commonwealth countries only rolled out the implications of the Beveridge Report of 1941 after WW2. See G. Verhoef, "From Friendly Societies to Compulsory Medical Aid Association: History of Medical Aid Provision in South Africa's Public Sector", Social Science History, 30, 4 (2006), pp 601-627; and G. Verhoef, "Wie moet sorg? Gesondheidsbeleid en Mediese Fondse in Vergelykende Perspektief in Suid-Afrika en Gemenebeslande, 1900-1970", in Historia, 16, 2 (2007), pp 19-51.

51. SA; 6/1/1/1/11, W. J. Bezuidenhoudt, Memorandum Groepversekering, 16/54.

52. The civil service on all three levels (national, provincial and municipal) was becoming more Afrikaans because Afrikaners were progressively appointed to the lower ranks of the civil service in the post-1948 National Party rise to power. See Giliomee, "The Afrikaner Economic Advance", pp 160-161.

53. The adverse economic conditions led to the unemployed setting themselves up as life insurance agents. Too many adopted “... doubtful measures of securing business" and failed. This prompted the formation of the Life Offices' Association in 1935, inter alia to curb such practices. 
Departments of Education in the different provinces were reluctant to establish a provident fund for the widows and orphans of teachers. The new generation Ideal Policy was offered to the organised teachers' profession and the professional teachers' associations endorsed it as the official policy of the associations (these were dominated by Afrikaans-speaking teachers, thus offering Sanlam a relatively captive market). Sanlam also marketed its policies to African teachers and other African professionals, both on an individual and group basis. ${ }^{54}$ The family income policy, the income protection policy and the family protection policy were offered on a group basis and endorsed as the official policies to these associations. These were taken up in September 1933 by the Transvaal Teachers Association; in May 1934 by the Free State Teachers' Association; and in December 1934 to the South African Teachers' Association. This did not constitute product innovation, but a strategic marketing innovation, since no other life office had established similar distribution channels to stakeholder groups. ${ }^{55}$

In the period up to the 1950s Sanlam developed no new products to shift its market share, but capitalised on the massive surge in Afrikaner nationalism following the 1938 centenary celebrations of the Great Trek. ${ }^{56}$ Sanlam embarked on an investment strategy that served a dual purpose. First, investment of policyholder funds was directed into equities delivering optimal returns. Indirectly, Sanlam used South African patriotism by telling its policyholders that through equity investments, they were participating directly in the mainstream of the economy: "building the economy for the people". The benefits of such investments accrued to policyholders, because Sanlam was a mutual life assurer. The second purpose was to rely on this burgeoning "nationalism" to strengthen the loyalty to the company and expand its market share.

A third dimension to Sanlam's strategy emerged towards the late 1930s. When Afrikaner leaders called the Ekonomiese Volkskongres in 1939 to address the persistent dilemma of white poverty, particularly among Afrikaners, Sanlam leadership played a pivotal role in proposing strategies of Afrikaner economic empowerment. Dr M.S. Louw, the Sanlam actuary, delivered a strong plea for empowerment through the development of entrepreneurship, supported by funding for emerging small businesses. His idea was to set up a finance house, similar to the finance houses of the mining industry, which could provide working capital in support of Afrikaner entrepreneurs desiring to set up small enterprises. ${ }^{57}$ In 1942 Federale Volksbeleggings (FVB) was established - a finance house to provide working

54. SA, Minutes of Dagelijks Bestuur, 23 September 1934.

55. SA, Minutes of Sanlam Board, 1933; 1934.

56. G. Verhoef, "The South African Economy in the Twentieth Century", in F. Pretorius (ed.) A History of South Africa. From the Distant Past to the Present Day (Protea Book House, Pretoria, 2014), pp 259-261; H. Giliomee, "Afrikaner Nationalism, 19021948", in Pretorius (ed.) A History of South Africa, pp 307-308.

57. SA, 6/1/7/; M.S. Louw Papers: Memorandum aan die Raad insake Finansieringsmaatskappy, 20 October 1938; Minutes, Sanlam Management, 20 April 1939. 
capital to new enterprises. Sanlam did not provide the capital: shares were sold to the public, motivated by the vision of economic empowerment developed so powerfully at the Volkskongres. As part of Sanlam's investment policy the company also acquired a stake in FVB. ${ }^{58}$

As Keller noted, management of insurance companies directed their attention increasingly to the companies' investment strategies. ${ }^{59}$ At the time of its establishment phase, Sanlam exercised a preference for long-term fixed interest loans and bonds, ${ }^{60}$ but the sense of responsibility to use the life office to contribute to the growth of the domestic economy, added investments in securities as an asset of national duty.

Another innovative investment opportunity was Bonuskor, or to give it its full name, the Bonusbeleggingskorporasie van Suid-Afrika or the Bonus Investment Corporation of South Africa, established in 1946 to invest policyholders' bonuses, if so requested, in equities. ${ }^{61}$ Policyholders could choose to re-invest bonuses earned on profit sharing policies either in the existing policies or to receive such bonuses as a cash bonus, which could either be invested in equities, specifically in higher risk investments such as preference shares, debentures and other securities deemed appropriate by its management, through Bonuskor, or take the cash. ${ }^{62}$ Bonuskor was a sign of Sanlam's entrepreneurial and strategic use of empowerment nationalism, patriotism and social responsibility appeal.

M.S. Louw acknowledged in his submission to the Sanlam Board that a life office had to be very careful about engaging in investments that were too risky, since it had a contractual responsibility to pay out on policies at maturity, or in the unexpected case of death. The anomaly for South Africa, Louw pointed out, was that credit institutions in South Africa controlled in excess of $£ 6$ million, of which less than 1 percent was invested in ordinary or preference shares of commercial or industrial concerns. He argued that the credit industry was eluding a very basic responsibility, namely to contribute to the building of a healthy commercial and industrial sector in South Africa. Management was well aware of its responsibility towards policyholders, but was convinced that investments in "sound and more lucrative" instruments could be found in equities. ${ }^{63}$ Policyholders were "educated" by the management of Sanlam,

58. G. Verhoef, "Die Stigting van Instellings as Werktuie in die Ekonomiese Opbouproses van die Afrikaner sedert die Anglo-Boereoorlog", in Tydskrif vir Geesteswetenskappe, 46, 2 (2006), pp 381-391; Verhoef, "From Friendly Societies ", pp 601-627; Verhoef, "Savings for Life", pp 118-163.

59. Keller, The Life Insurance Enterprise, p 21.

60. SA, 6/1/1/5, W. J. Bezuidenhoudt; and R. Adams, "Die ver-Suid-Afrikanisering van die Suid-Afrikaanse ekonomie: 'n Studie van SANLAM (1918-1980)", MA dissertation, Stellenbosch, 2011.

61. SA, 6/1/7, M.S. Louw Memorandum, 22 January 1945.

62. SA, Minutes of Sanlam Management, 3 March 1944; 26 May 1944; Minutes of Sanlam Board, 28 November 1945.

63. SA, 5/2/1, J. Vorster, 19 December 1945, p 4. 
through Bonuskor, in extending savings into higher risk investments - all justified in the name of building the South African economy and thereby contributing to employment creation - the appropriate strategy to overcome the poor white problem. Sanlam, as a mutual life assurer portrayed itself as the vanguard of the policyholders, of whom at that time more than 80 percent were Afrikaans-speaking persons. ${ }^{64}$

The innovative investment strategy encouraged other life offices in South Africa to invest actively in larger than portfolio investments in emerging sectors of the economy. Sanlam skilfully used this strategy at a time of rising Afrikaner nationalism, to facilitate Afrikaner economic empowerment. Life offices generally invested in government and other public utilities' securities, ${ }^{65}$ but not in the same proportions Sanlam eventually did. ${ }^{66}$ FVB was a "greenfields" investment and posed a potential risk because Sanlam did not manage it, but it earned Sanlam goodwill and evolved as a learning curve for emerging Afrikaner businessmen.

Towards the early 1950s these initiatives positioned Sanlam in a strong growth trajectory.

Table 1: Total premium income, industry v Sanlam, 1929-1950 (£'000)

\begin{tabular}{|l|l|l|l|}
\hline Year & $\begin{array}{l}\text { Long-term Insurance } \\
\text { sector }\end{array}$ & Sanlam & $\begin{array}{l}\text { Sanlam as \% of } \\
\text { industry }\end{array}$ \\
\hline 1929 & 4960 & 241 & 4,85 \\
\hline 1950 & 23245 & 4104 & 17,65 \\
\hline $\begin{array}{l}\text { Annual compound } \\
\text { growth, } \\
1929-1951 \%\end{array}$ & $8 \%$ & $15,2 \%$ & \\
\hline
\end{tabular}

Source: Summaries of Returns Deposited by Insurance Companies with the Treasury, 19251944; Annual Reports: Registrar of Insurance, 1944-1952.

64. SA, Memorandum to the Board, 20 February 1963.

65. The Insurance Act, No. 27 of 1943 ushered in a period of 45 years of explicit statutory investment prescriptions for life insurance companies. Life insurance companies were obliged to invest fixed proportions of their liabilities in government, municipal and utilities' stock, in government bonds and bills and in retirement annuities and pension funds. For 40 years statutory prescribed investments limited the ability of long term insurers in South Africa to seek optimal investment returns of choice. See Verhoef, "Life Offices to the Rescue", pp 145-166.

66. M. Lipton, Capitalism and Apartheid, 1910-1986 (David Philip, Cape Town, 1986), p. 242 noted that Sanlam had the largest equity investment on the JSE of all SA life offices. The investment in local equities was also mandated by exchange control and the lack of FDI in the wake of emerging international pressure against the NP government. See F.S. Jones and A.L. Müller, The South African Economy (Palgrave Macmillan, London, 1992), pp 223-224, 327 and 352. 
Table 1 above shows the strong growth of Sanlam, outperforming the total life assurance industry by a factor of almost two and growing its relative position from 4.85 percent in 1929 to 17.65 percent in 1950. The company mobilised contractual savings among formerly uninsured people. Later, Sanlam "educated" its policy holders to other investment opportunities, albeit motivated by nationalistic ideals, but successfully strengthening the participation of Afrikaners in the South African economy.

\section{Market growth, isolation and internalisation, 1950-1990}

In the context of the wider business history of South Africa, strong economic growth after the war sustained industrial growth. Local manufacturing growth exceeded 80 percent, until halted by the international recession caused by the oil price crises of the mid-1970s. ${ }^{67}$ This was a period of worldwide growth, but for South Africa an initial period of strong growth followed by creeping international isolation as a result of the implementation of the policies of apartheid. State intervention in the economy reached new levels with the policy of industrial decentralisation aimed at locking black labour into the designated so-called "homeland" areas, while stimulating industrial enterprise outside the industrial core of South Africa. ${ }^{68}$ Business expanded during the prosperous 1950s and 1960s, but soon suffered from declining productivity caused by low levels of skills development and education of the workforce. As the 1970s wore on this growing black workforce was also becoming increasingly militant, seeking the termination of the policy of separate development and participation in a unitary democracy. ${ }^{69}$

The financial services industry, especially the insurance market, became increasingly insulated, but offered a much needed investment outlet to South Africans. ${ }^{70}$ The domestic insurance market was highly competitive and life offices offered a comparable basic range of life policies - with profit or non-profit policies, simple reversionary bonus, compound reversionary bonus, cash bonus, whole life policies, endowment assurance and term assurance. Sanlam had led the way with special types of policies providing for family income protection and children's provisions. In the post-war years Sanlam was the only insurer that had made noticeable inroads into the market of the other life offices.

67. Jones and Müller, The South African Economy, pp 176-177; 278-288; Feinstein, An Economic History, pp 143-149.

68. J. Nattrass, The South African Economy: Its Growth and Change (Oxford University Press, Cape Town, 1982), pp 180-183.

69. Feinstein, An Economic History, pp 162-165; Nattrass, The South African Economy, pp 232-234 and 281-283.

70. J. Singleton and G. Verhoef, "Regulation, Deregulation and Internationalisation in South African and New Zealand Banking", Business History, 52, 4 (2010), pp 543-544; R.W. Vivian, "South African Insurance Markets", in Cummins and Venard, Handbook of International Insurance, p 681. 
Total premium income of long term insurers in South Africa rose from R51million ${ }^{71}$ in 1950 , to R21 807million in 1990, or from 1.1 percent of national income to 8.3 percent of national income in 1990. The total premium income of the long term insurance industry rose from 10.7 percent of household savings (at current prices) in 1950 to an impressive 456.5 percent in 1990. In 1990 long term insurance premium income was $7.47 \%$ of GDP, third highest only to South Korea and Japan. Contractual savings (in pension funds and with insurers) rose from 22 percent of personal savings in 1970 to 57.8 percent of personal savings in $1990 .{ }^{72}$ In response to financial deregulation long term insurers gradually expanded their services into the financial services domain. This trend manifested rapidly in South Africa after 1990. The growth in the demand for insurance and other wealth products was directly linked to the increasing socio-political instability, high inflation and the creeping isolation of South Africa. South Africans could not invest abroad freely because of exchange controls and therefore created a captive market for local investment products - those which life assurers typically catered for.

Table 2: Total premium income, industry v Sanlam, 1950-1990 (R'm)

\begin{tabular}{|l|l|l|l|}
\hline Year & $\begin{array}{l}\text { Long-term Insurance } \\
\text { sector }\end{array}$ & Sanlam & $\begin{array}{l}\text { Sanlam as \% of } \\
\text { industry }\end{array}$ \\
\hline 1950 & 51 & 8 & 17,65 \\
\hline 1990 & 21807 & 7428 & 34 \\
\hline $\begin{array}{l}\text { Annual compound } \\
\text { growth, } \\
1950-1990 \%\end{array}$ & $16.8 \%$ & $19.15 \%$ & \\
\hline
\end{tabular}

Source: Annual Reports, Registrar of Insurance, 1950-1990

In the forty years after 1950 Sanlam strengthened its relative position in the life assurance market from collecting 17.6 percent of total premium income, to 34 percent of total premium income (see Table 2 above) Sanlam's premium growth outstripped industry growth of 16.8 percent by 19.15 percent.**

This was achieved through the improvement of existing products, and linking life policies to new investment instruments whereby policyholders could benefit from the strong growth in the economy and the subsequent increase in equity values. Existing products were also marketed on an extended group basis, which expanded Sanlam's market penetration significantly and took the advantages of life assurance to the lower income groups. Secondly Sanlam continued its investment in so-called 'strategic' investments, following on from the initiatives of the Ekonomiese Volkskongres of 1939, whereby the concentration of Afrikaner capital reached new dimensions causing a precarious position for the life office.

71. In 1960 the South African currency changed from the British Pound ( $£$ ) sterling to the South African Rand (ZAR), at a rough conversion rate of $€ 1=\mathrm{R} 2$.

72. South African Reserve Bank (SARB), South Africa's National Accounts, 19461990 (Government Printer, Pretoria, 1992). 


\section{Product innovation}

In the robust competitive environment of the post-war period Sanlam developed new group life insurance schemes for a variety of occupational entities. A total of 16 group life schemes ${ }^{73}$ were established since $1954 .{ }^{74}$ In 1959 Sanlam introduced the first retirement annuity policy in South Africa. ${ }^{75}$ This signifies two important trends in society: higher levels of income and a growing investment orientation among policy holders, since retirement annuities were principally investment products. Sanlam identified an opportunity to take advantage of the strong growth in the economy (real national income rose by 8.7 percent per annum between 1948 and 1961), the postwar demand for retirement provision and the improved standard of living of the South African population, including Afrikaners. ${ }^{76}$

When the Minister of Finance finally announced a tax concession in June 1960 (to a maximum of $£ 300$ ) to self-employed persons for contributions towards their own 'pension schemes', Sanlam established a general retirement annuity fund open to all qualifying applicants. This allowed them to market the new general fund to a much wider client base on the back of the new tax concession. Sanlam used this product to target what it came to refer to as the 'senior market', i.e. the high income market. This target market was professional people, self-employed people and any person desiring to add retirement provision to existing pension provisions. It also included persons belonging to provident funds, to which the tax concession was not extended. ${ }^{77}$ As underwriter to the PPS Provident fund for professional persons, Sanlam had them in mind.

Sanlam anxiously wanted to protect the advantage it had secured in the annuity market. Therefore a special arrangement was made with the Post Master General for a business reply service to be granted to Sanlam immediately after the

73. SA ,1/2/1/3/3/, Vol. 30, Group Insurance; Rate Books, 1954, 1967 and 1974.

74. SA, Hospital Employees, 1 October 1958; Prison Services Employees, 1 December 1958; Municipal Employees, 1 June 1959; Teachers, 1 May 1954; Post Office Employees under trusteeship of the ATKV, 1 September 1958; Salaried Staff of the South African Railways \& Harbours (SAR\&H), 1 February 1959; SAR\&H Employees' Union, 1 March 1959; SAR Police Staff Association, 1 November 1958; SAR\&H, Running and Operational Staff Association, 1 April 1959; Public Servants' Association, 1 July 1958; ISCOR, 1 July 1959; Iron, Steel Allied Industries Union, 1 September 1959; South African Police, 1 December 1958; Professional Provident Society (PPS), 1 November 1958; South African Army Scheme Fund, 1 June 1957; South African Air Force Fund, 1 July 1958; South African Navy Fund Scheme , 1 May 1958.

75. Sanlam Product List, August 2013.

76. Sadie estimated that by the early 1960s Afrikaners' personal income as a ratio of that of English-speaking South Africans had risen from 47.6: 100 in 1946, to 64.6: 100 in 1960 and 69.9: 100 in 1970. See J.L. Sadie, "The Fall and Rise of the Afrikaner in the South Africa Economy", Stellenbosch Annale, 2002/1, p 56.

77. SA, 1/2/1/6, Senior Market Development, 12 June 1960. 
Minister's tax rebate announcement. ${ }^{78}$ Sanlam prepared and mailed large numbers of letters informing its existing policyholders of the new tax rebate and invited them to take up retirement annuities with Sanlam. This need to capitalise on its advantage, led to the Head Office's requesting that all leave be cancelled for the period immediately following the Minister's announcement. ${ }^{79}$ The leadership of Sanlam in retirement annuities was acknowledged when Sanlam was appointed the underwriter of the National Central Annuity Fund (CAF). ${ }^{80}$ Sanlam soon added additional investment options to its retirement annuities, such as investments in unit trusts, the new investment vehicle of the mid-1960s. ${ }^{81}$

The ordinary life, endowment and annuity products remained operational in a very competitive life market. The only strategy to gain market share for Sanlam was to think radically new. New products were developed by the actuarial department, where Sanlam employed many of the bright young minds the company had supported with bursaries to study towards actuarial science and statistics. ${ }^{82}$ The first was the introduction of 'with profit' policies, or policies sharing in the profits of Sanlam's investments in 1962, but these were overhauled entirely by 1969. An entire new range of policies were introduced. These were the 100-Plus policy range, introduced 20 May 1969. The 100-Plus policies included whole life policies, endowment policies, savings plan policies and children's assurance. ${ }^{83}$ This series offered an investment opportunity by investing the whole premium in a dedicated high return investment, thus creating a personal and therefore unique investment fund, administered by Sanlam. These policies ensured long-term returns. A portion of the 100-Plus fund was invested in Government securities, prescribed investments and in cash deposits. This combination changed as interest rate fluctuations determined the choice of alternative investment products. ${ }^{84}$

The strong growth in the South African economy during the 1960s and 1970s stimulated the appetite for rewarding equity investments. Greater flexibility in wealth product choices became increasingly popular as security in the country deteriorated

78. Sanlam was not favoured above any other life assurer in this arrangement made with the postmaster general. Sanlam was simply the only innovative life office, who had pioneered the introduction of RAs and requested such a service. Had any other application been received, the same service would probably have been extended.

79. SA, 1/2/1/6, Letter J.A. Vorster - Field Staff, 6 May 1960.

80. SA, $1 / 2 / 1 / 3 / 4$, Special Tariffs, 9 May 1967. Sanlam was again not favoured by being appointed underwriter to the NCAF. Applications were made to the state and the best was selected. Sanlam was after all, the leader in the industry.

81. SA, 1/2/1/3/4, Special Tariffs: Memorandum, 22 August 1967.

82. SA, B23, Memorandum to Sanlam Board, Bursaries to students in mathematics, 25 October 1955; Memorandum to Sanlam Board, 17 August 1962, Bursaries to matriculates. M.H. Daling, later the CEO of Sanlam, was a recipient of a Sanlam bursary and qualified as an actuary from the University of Pretoria. So was D.K. Smith, later CEO of Sanlam and current chairperson of the Board of Sanlam.

83. SA, 1/2/1, Product Development A/101, August 1970.

84. SA, $1 / 2 / 1 / 2 / 1$, Product Development, Notice of 17 November 1970; Cape Times, 25 July 1968. 
following the Soweto uprising in 1976 and the subsequent political instability leading to the state of emergency in 1985 and 1986. 85 Insurance, in a variety of forms, offered society a means to mitigate the risks involved in the domestic conditions. The benefit of new investment products to policyholders was that the return earned on the fund investments, were tax free in the case of retirement annuities. Other investors paid tax on investment income, but the retirement funds remained under the control of the life assurer. This Sanlam investment innovation linked the benefits of ordinary life policies to full and immediate participation in the exceptional growth of the assets in which the premium was invested. Policies could be converted to any conventional policy at the request of the policyholder, the proceeds could be received in regular pension pay-outs, or policyholders could request regular withdrawals which in effect meant that a part of the policy was surrendered and the cover would be reduced accordingly. ${ }^{86}$ The innovation of the 100-Plus series was in the potentially higher investment returns, which could result in higher maturity values. Past policies had a fixed maturity value, but the 100-Plus policies linked a policyholder's unique profile to investments, while the reversionary bonus policies' maturity value depended on the bonus declared. The 100-Plus series introduced flexibility in life insurance, which Sanlam marketed as its endorsement of the mutual character of the company - that all policyholders should share in the benefits of the abilities of management to enhance policyholder value. Sanlam's policyholders benefited directly from the company's investment management capabilities and showed the sensitivity of the company to the needs of policy holders.

Longevity means success. The 100-Plus policy series remained in force until the mid-1980s when Sanlam revolutionised the life assurance market again with yet another innovative product.87 In August 1985 Sanlam introduced the "One Policy". The One Policy was a universal policy, versatile and adaptable to the needs of the middle and high income market. Sanlam was the first South African company to introduce policy flexibility. Sanlam had recognised the upward mobility of its policyholder base. The time was ripe to offer investment products aimed at the middle to high income market segment. The domestic volatility made people to seek flexibility in wealth provision and investments. The One Policy offered a policy structure responsive to a wide range of needs a policyholder could desire to have addressed in life assurance. Other life offices soon had similar universal policies, but Sanlam added a unique element in its offer to its existing policyholders: they could convert from any existing policy into the One Policy. The combination between life cover and investments could be adjusted as often as the policyholder desired and no maturity date was mandatory upon signing the policy contract. Policyholders could also adjust life and disability cover at any time and for any term. ${ }^{88}$ The One Policy was also referred to as the 'One Door Opener', because of the product flexibility and the

85. Lipton, Capitalism and Apartheid, pp 344-47; 377-378.

86. SA, 1/2/1, Product Development A/102, Rate Book, August 1970.

87. SA, Product List, August 2013. Although a similar concept was marketed in the USA, Sanlam developed the first actual life product in South Africa.

88. SA, 1/2/1, Product Development: One Policy, 30 September 1984. 
multiple payment options offered. ${ }^{89}$ Sanlam opened the door to an optimal client needs' response and in 1986 already added an option for a planned short-term maturity term policy by introducing the 'Planned Premium Term' option in the One Policy. ${ }^{90}$

The media admitted that Sanlam had caused a massive awakening in the life assurance market in South Africa - more than 2000 One Policies were sold within two weeks and by the end of April 1987 a total of 184000 One Policies were on the Sanlam books. The significance of this development for history is the responsiveness of business to the changes in the country and subsequent needs of the people. The other life offices were swift to respond to the challenge. By 1987 Sanlam admitted that its advantage had largely been eroded. ${ }^{91}$ Other life offices offered superior trauma and contingency cover in the policies competing with the One Policy. Especially SA Mutual undercut Sanlam in terms of minimum entry premiums, maximum cover and better cash values in their competing product 'Flexi Life'. ${ }^{92}$ In the life market this resulted in an outright tariff war - the short term benefit to Sanlam was that the company pioneered the single comprehensive life product phenomenon, but as soon as competition caught up with the innovation, the playing field was levelled.

The success of Sanlam with the One Policy was remarkable given the dire context of international economics in the mid-1980s. ${ }^{93} \mathrm{On}$ home turf growing disinvestment, the calling of a state of emergency in 1985/86 and the 1986 American banks' refusal of a roll over for South African debt amounting to US\$13.6 ${ }^{94}$ led to fears of a currency crisis and forced the South African Government to declared a debt standstill in August 1986. ${ }^{95}$ The financial services sector remained relatively strong and South Africa followed international financial deregulation trends leading to massive domestic market consolidation and a concentration of banks and financial services institutions. ${ }^{96}$ Socio-political stability only started to consolidate after the country's first democratic elections in 1994.

89. SA, F22/11/85, Sanlammer, 53, 46 (1984), p 1.

90. SA, 1/2/11/2, News Flash, Marketing Actuary, 20 March 1986. This allowed the policyholder an endowment option for a fixed term, minimum ten years, maximum the shorter of 30 years and the termination of the policy before the age of 75 .

91. SA, 1/2/1, Product Development, C.J. v R. Memorandum, 12 June 1987.

92. SA, 1/2/1, Product Development, C.J.v R. Memorandum, 12 June 19 87: Appendix 6.

93. Economic growth in industrial countries dropped to around 3\%; inflation hovered around 16\%; real growth went down to $3.2 \%$; and personal savings dropped below $3 \%$ of GDP. The average rate of growth of long-term insurance total premium income dropped to $19 \%$ compared to an average rate of growth of total premium income of $24 \%$ the previous five years. See SA, 7/5/2, LOA, Annual Report, 1985, p 1.

94. Financial Times, 26 November 2009.

95. SA, Government Press Release, 15 August 2001.

96. Singleton and Verhoef, "Regulation, Deregulation and Internationalisation", pp 536563; G. Verhoef, "Concentration and Competition: The changing Landscape of the Banking Sector in South Africa, 1970-2007", in The South African Journal of Economic History, 24, 2 (2009), pp 157-197. 
The growth in Sanlam's premium income was strong after the introduction of industry revolutionising products. Sanlam's premium income rose from R32 million in 1962 to R255 million after the introduction of the 100-Plus policies. Then the One Policy catapulted Sanlam's premium income to R3 527 million by 1987 and R12 966 million just before demutualisation in 1997. ${ }^{97}$ The movement of investment income followed in tandem with premium income, because Sanlam linked life policies increasingly to investment products. That was the Sanlam strategy - to grow its market share from its mutual life assurance basis. This development is also reflected in the distribution of Sanlam's assets. When comparing the distribution of Sanlam's assets during the 1960s to that of the late 1990s, it can be seen that the asset base shifted from fixed property to equity as market returns justified a larger exposure to shares.

In the early 1960s Sanlam's assets comprised of $14 \%$ in fixed property, $22 \%$ in ordinary equity, $13 \%$ debentures, $22 \%$ in public sector securities, $20 \%$ in policy loans and $9 \%$ in cash and other assets. The volatility in domestic conditions was reflected in the new asset distribution structure by the late 1990s. Sanlam's assets were for $6 \%$ in fixed and other operating assets, $9 \%$ in fixed property, $12 \%$ in interest bearing assets, $9 \%$ in public sector securities and $54 \%$ in equity. Thereby Sanlam mirrored the broad characteristics of the South African economy and facilitated the transfer of the benefits of its successful assessment of the changes, to its policy holders.

\section{Empowerment of Afrikaners}

Innovation in the life assurance market slowed down towards the late 1990s as the investment demand shifted to new wealth products. Life assurers consolidated their position. They focused on improved profitability by reducing costs and managing new generation investment portfolios optimally. Sanlam's continued investments in sectors of the economy where Afrikaners had been poorly represented, was an empowerment strategy, but simultaneously also a strategy to develop its own market. Demand for life assurance and related investment products was stimulated as the general standard of living of South Africans' improved. Sanlam had developed an exceptionally large portfolio of so-called 'strategic investments'. These were investments linked to the economic empowerment of Afrikaners. The acquisition started in 1942 with the establishment of FVB. In the period between 1950 and 1990 Sanlam built-up a portfolio of shares in the new Afrikaner-managed mining house Federale Mynboumaatskappy, (Fedmyn) established in 1953. Fedmyn expanded operations organically from the ownership of two small coal mines to the acquisition of shares in small gold mining companies, to buying General Mining Ltd from the Anglo American Corporation in 1963. The success of General Mining led in 1974 to Fedmyn conducting a hostile bid for Union Corporation, the UK listed gold mining company. After the acquisition of Union Corporation, the name of the merged

97. SA, Sanlam Annual Reports, 1962-1998. 
operating company was changed to Gencor, the second largest gold mining company in South Africa.

Gencor inherited many industrial concerns from the Fedmyn investment portfolio, and by the early 1990s Gencor was no longer a focused mining concern. The expansion of industrial acquisitions by FVB also resulted in some underperforming companies, which impacted negatively on Sanlam's investment returns. Sanlam had also invested in the establishment of Trust Bank in 1956, a general bank targeting small to medium size credit to entrepreneurs and households. Trust Bank evolved into the bank in a larger banking group under the holding company Bankorp, housing a building society, a merchant bank, hire purchase and leasing banks, etc. Bankorp ran into liquidity problems towards the late 1980s and the CEO of Sanlam, Dr F J du Plessis personally took over the executive management of the bank.

The size of these non-core investments and the underperforming nature of many of the underlying concerns resulted in a Sanlam decision in 1985 to establish an investment company, Sanlam Beleggingskorporasie (Sankorp) to which those assets were transferred. The clear message was to return those investments to profitability, to restore focus and rationalise Sanlam's shareholding in the different sectors of the economy. In these turbulent economic times Sanlam could not afford weak performance of its investment portfolio. Industrial, mining, financial services, building and construction, transport and hospitality services were all part of this diversified investment portfolio. Sanlam was a life office and lacked the capacity to manage such diverse sectors efficiently.

When Sanlam kept adding companies to its portfolio in flat investment markets in 1983 and 1984, Fred du Plessis and Marinus Daling (then investment chief of Sanlam) took scathing criticism. Sanlam was criticized for merely wanting to control and dissipating policyholders' funds into a web of empire-building. The asset base of Sanlam was R1 billion in 1975, but mushroomed to R6 billion in 1984, growing annually by the size of its assets in 1975. Sankorp appointed business strategists, mangers with a proven track-record in the different sectors to effect strategic rationalisation. ${ }^{98}$

Sanlam's exposure to the different sectors in the South African economy by the mid-1980s was simply over-extending the typical portfolio investments of life assurance companies. In the mining sector Sanlam had investments to the total of R532 million; in financial services such as banks and other insurance companies it was R226 million; in the transport sector it was R79 million; R73 million in the electronics industry; R17 million in engineering; 194 million in industrial holdings conglomerates and another R47 million in retail. ${ }^{99}$ The massive restructuring of the different diversified industrial, mining and financial conglomerates under the control of Sankorp improved performance in focused conglomerates - in construction,

98. "Investing in Security", Financial Mail, 30 November 1990, p 23; Verhoef, "Savings for Life", pp 118-163.

99. SA, 5/2/1, Minutes of Sanlam Board, 24 November 1984. 
mining, industry, financial services and electronics. Sankorp was the driving force behind the first conglomerate unbundling exercise in South Africa - that of Gencor in 1993.100 Massive value was unlocked by building down of holding company structures affecting non-core mining interests, which eventually allowed Gencor to focus on mining. Before unbundling Gencor shares traded at a 21 percent discount on the Johannesburg Securities Exchange. ${ }^{101}$ The unbundling exercise unlocked R2.5 billion for Gencor and the holding company Sanlam.102 The unbundling of Gencor was only one of such corporate unbundling exercises Sankorp - also Murray and Roberts, the construction conglomerate and Malbak the industrial holding conglomerate. By the end of 1996 Sankorp transferred the much smaller, streamlined investment portfolio back to Sanlam, insuring investment manoeuvrability and a chance of becoming a major player in the financial services arena. ${ }^{103}$

Sanlam's exposure to industrial investments was the result of its goal of facilitating the growth of the South African economy by investing in domestic enterprises and thereby also empowering Afrikaners to acquire a meaningful share in the economy of their own country. Part of Sanlam's extensive non-core investments was off course also explained by international isolation since the 1970s and exchange control. This is significant for the study of South African business simply because of the sheer size of the Sanlam Empire and the impact it had on competition in the domestic market. Not all investments Sanlam had made were sound, but did contribute to the rise in the contribution of Afrikaner-controlled enterprises to the private sector economy as follows:

Table 3: The contribution to the private sector economy by Afrikanercontrolled enterprises (\%)

\begin{tabular}{|l|l|l|}
\hline & $\mathbf{1 9 4 8 / 9}$ & $\mathbf{1 9 7 5}$ \\
\hline Agriculture & 85 & 82 \\
\hline Mining & 1 & 18 \\
\hline Manufacturing \& construction & 6 & 15 \\
\hline Commerce & 25 & 16 \\
\hline Transportation & 9 & 15 \\
\hline Liquor \& Catering & 20 & 35 \\
\hline Professions & 16 & 38 \\
\hline Finance & 5 & 25 \\
\hline Miscellaneous & 27 & 45 \\
\hline Aggregate & 24,5 & 27,5 \\
\hline Aggregate excluding agriculture & 9,6 & 20.8 \\
\hline
\end{tabular}

Source: J.L. Sadie, "The Fall and Rise of the Afrikaner in the South African Economy", Stellenbosch Annale, 2002/1, p 28.

100. Verhoef, "Savings for Life", pp 118-163.

101. SA, Sankorp, Board Meeting, 10 June 1992.

102. SA, Sankorp, Board Meeting, 13 April 1994.

103. SA, Sanlam Board, Minutes, 8 April 1995; Sankorp, Board Meeting, 26 June 1996. 
The empowerment achievement reflected in Table 3 cannot only be ascribed to Sanlam, but also to Sanlam's investment facilitated opportunity to entrepreneurial aspirations that afforded Afrikaners equity participation in sectors of the South African economy from which they had been marginalised. Indirectly Sanlam had developed a market for its policies by actively contributing to the development of a truly national South African economy by empowering those outside the mainstream economy. In 1921, more than 90 percent of Sanlam policyholders were Afrikaans speaking and English speakers comprised less than 10 percent, but by the early 1990 s the English-speaking policyholder base had grown to about 40 percent of Sanlam's policyholders. ${ }^{104}$ Sanlam was establishing itself as a truly national South African company - Sanlam's policyholder profile changed from predominantly white (only 5\% African policy holders between 1922 and 1943) to just more than 33\% African policyholders by the early 1990s. ${ }^{105}$ Sanlam was gradually growing its market share by its focus on the development of the local South African economy in the interest of its changing policy-holder profile.

This change in its policyholder profile was not unique to Sanlam - similar trends manifested at the other life offices, but Sanlam succeeded in doubling its market share between 1950 and 1990. The entire South African society was transforming, but Sanlam took the initiative in two respects, which strengthened its market penetration. The first initiative was with life assurance for HIV positive persons. The second was the conclusion of the first Black Economic Empowerment transaction in South Africa.

\section{HIV/Aids life cover}

While restructuring the Sanlam strategic investments, Sankorp carefully researched the changing socio-economic conditions in South Africa and advised Sanlam on ways to address such changes. ${ }^{106}$ The insidious growth of HIV/Aids among South Africans encouraged Sanlam to engage through social responsibility initiatives with organisations attempting to combat the virus infection. ${ }^{107}$ Sanlam was the first life assurer in 1988 to address the issue of cover to persons living with HIV/Aids. Sanlam included an Aids exclusion clause only on their life policies. ${ }^{108}$ On the ordinary applications to Sanlam for life cover, screening procedures were introduced to identify the HIV/Aids status of the applicant. For policies without life cover, or life policies with cover less than or equal to the minimum cover, for investment policies or children's polices or policies that form part of an investment plan, no HIV/Aids

104. SA, 5/2, J.V., Sanlam Annual Report, 2004, pp 22-23.

105. Finance Week, 10-16 June 1993, p 28; Halleen, From Life Insurance, pp 119-124.

106. SA, Sankorp, Confidential Memoranda, 13 June 1986 and 14 July 1987.

107. SA, Sanlam Life Board Minutes, 10 January 1989.

108. The aim was to send out a message to existing policyholders that Sanlam was protecting their interests, but did not institute exclusion clauses for any investment product, or children's policies, or on polices with cover of less than or equal to eight times the first year's premium. 
disclosures were required. ${ }^{109}$ If relevant, HIV/Aids cover was calculated on age and blood count levels. ${ }^{110}$ Company policy was that identification of the prevalence of HIV/Aids within two years of the inception of a life policy would result in the expiry of the life cover. Should HIV/Aids infection be diagnosed more than two years after the inception of a policy, benefits would be paid for a restricted period. ${ }^{111}$ They also established a HIV/Aids standing committee to assist with education programmes and collaborated with the Actuarial Society's Aids Committee on issues such as genetic and HIV testing. ${ }^{12}$ Sanlam took the first step towards benefits for persons living with HIV/Aids and the other life offices followed suit.

\section{Sanlam and Black Economic Empowerment}

Business in South Africa was concerned about the future stability of the political and economic wellbeing of the country and from within Sanlam came the suggestion that Sanlam should acknowledge the aspirations of black people to share in the ownership of the mainstream of the economy. ${ }^{113}$ After direct and wide consultation with black leaders, Sankorp concluded the first Black Economic Empowerment (BEE) transaction in 1993 in South Africa. Sanlam sold a portion of its controlling interest in its blue chip subsidiary Metropolitan Life to a new company, Corporate Africa, owned by black leaders. A holding company of Metlife, Methold, was formed jointly with Sankorp and issued shares in Methold - shares were only available to black buyers. Strict conditions were set for acquisition to prevent undue concentration of shareholding in order to empower as many black people as possible. ${ }^{114}$ Sanlam/ Sankorp sold 20 percent of its remaining interest in Metlife to Methold.115 The transaction was finally concluded in August 1994 and the name of the holding company, Methold, was changed to New Africa Investments Limited (NAIL). By the early 1990s NAIL was the largest black owned company listed on the Johannesburg Securities Exchange. ${ }^{116}$

Similar BEE transactions followed in South Africa, also by other insurance companies. Sanlam, via Sankorp was the first to do so and thereby strengthened its image as a South African company committed to the empowerment of the people of South Africa - first marginalised Afrikaners and later black South Africans.

109. SA, 1/2/1/1/2, Marketing Memorandum, $90 \mathrm{MCT} / \mathrm{cb}, 29$ March 1989.

110. SA, 1/2/1, Product Development Memorandum, 20 October 1994.

111. SA, $1 / 2 / 1$, Product List, 20 January 1997.

112. SA, 7/5/1, LOA Minutes, 10 February, 1995.

113. SA, Sankorp, Board Minutes, 5 May 1987; Sankorp, Confidential Memorandum, 18 August 1987.

114. SA, Sankorp, Board Minutes, 14 April 1993, 11 July 1993 and 9 February 1994.

115. SA, Sankorp, Management Minutes, 1 June 1994.

116. SA, Sankorp, Management Minutes, 3 August 1994 and 7 September 1994. 


\section{Conclusion}

Sanlam developed a strong position in the long-term insurance market in South Africa by the early 1990s. This was achieved by highly motivated nationalistic and business minded leadership; by employing the best in the industry and nurturing (educating) its own bright young scholars, and operating as a "family" for many years, but being willing to open up the family to include extended family members of a multi-cultural nation. As a life office, Sanlam was innovative on three levels: in market strategy; in product development; and in empowerment strategy.

Initially, Sanlam focused broadly on the Afrikaner family and the individual breadwinner but later pioneered group benefits and by the late 1990s administered more than 1950 group benefit schemes. This strategy perpetuated its original vision of "educating" the uninsured to provide for their families by means of life cover. In this educating role - the necessity of financial stability for the family - Sanlam embraced the change in the policyholder profile to enhance inclusivity. As suggested in the literature on process and product innovation in the insurance industry, the phases of product innovation in the history of Sanlam coincided with a downturn in the business cycle (the 1920s, the later 1960s and early 1970s, and with the One Policy in the mid-1980s) when the company capitalised on high interest rate environments and a slowdown in industrial growth. Innovations implied higher premiums and underwriting costs, but the rising living standards of the Sanlam policyholder base, as well as the prudent cost management practices in Sanlam, supported ongoing innovation. The introduction of the first life assurance product for HIV positive persons and Black Economic Empowerment initiatives in South Africa, underlines Sanlam's market responsiveness.

Sanlam was the first South African mutual life office to de-mutualise in 1998, setting the domestic trend. ${ }^{117}$ The choice of the mutual form of organisation is explained by the fact that the most successful life assurance companies in South Africa were mutual. This means that the construction of trust and confidence in the long term industry aligned well with the concept of a shared destiny. The foreign assurers were suspect for serving shareholders' needs and not giving priority to the interests of policyholders. Furthermore the risks associated with innovation were mitigated by the close relationship of trust and confidence constructed with the company's policyholder base on the platform of mutuality, a shared destiny in South Africa and the shared responsibility to assist in growing the South African economy, to which policyholders were made full partners. Under conditions of political isolation this sense of shared destiny was strengthened. Policyholders were loyal to their company and the company looked after them. Once South Africa's political context changed and re-entered the global market, the inward-looking strategy had to

117. M. Keneley and G. Verhoef, "Pressures for Change in the Australian and South African Insurance Markets: A Comparison of Two Companies", Competition and Change, 2, 15 (2011), pp 136-154; G. Verhoef, "Mutuality and Regulation: The Transition from Mutual to Public in the South African Long-term Insurance Industry", Journal of Economic and Financial Science, 2, 5 (2012), pp 573-596. 
change. Demutualisation was the strategic choice of a vehicle to take Sanlam into the expanded world, now also with a much expanded policyholder base. As a diversified financial service company, Sanlam entered a different market from life assurance in 1918. Key characteristics such as national social engagement and innovative product development assisted the company to sustain and develop its market, albeit now in a wider functional context, and set the tone for Sanlam's new insurance frontier: Africa. ${ }^{118}$

118. Currently Sanlam has the largest Pan-African footprint of insurance groups based on number of countries and contribution to the overall consolidated group. 